Prepared in cooperation with the University of Delaware

\title{
Continuous Resistivity Profiling and Seismic-Reflection Data Collected in April 2010 From Indian River Bay, Delaware
}

Open-File Report 2011-1039 



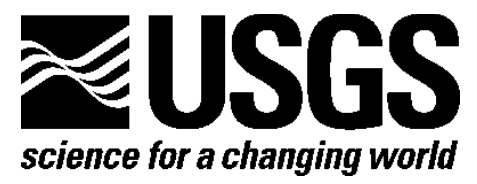

Prepared in cooperation with the University of Delaware

\section{Continuous Resistivity Profiling and Seismic-Reflection Data Collected in April 2010 From Indian River Bay, Delaware}

By V.A. Cross, J.F. Bratton, H.A. Michael, K.D. Kroeger, Adrian Green, and Emile Bergeron

Open-File Report 2011-1039

U.S. Department of the Interior

U.S. Geological Survey 


\section{U.S. Department of the Interior \\ SALLY JEWELL, Secretary}

\section{U.S. Geological Survey \\ Suzette M. Kimball, Acting Director}

U.S. Geological Survey, Reston, Virginia: 2014

For more information on the USGS-the Federal source for science about the Earth, its natural and living resources, natural hazards, and the environment-visit http://www.usgs.gov or call 1-888-ASK-USGS

For an overview of USGS information products, including maps, imagery, and publications, visit $h$ ttp://www.usgs.gov/pubprod

To order this and other USGS information products, visit $h$ ttp://store.usgs.gov

Suggested citation:

Cross, V.A, Bratton, J.F., Michael, H.A., Kroeger, K.D., Green, Adrian, and Bergeron, Emile, 2013, Continuous resistivity profiling and seismic-reflection data collected in April 2010 from Indian River Bay, Delaware: U.S. Geological Survey Open-File Report 2011-1039, 23 p., http://dx.doi.org/10.3133/ofr20111039.

Any use of trade, product, or firm names is for descriptive purposes only and does not imply endorsement by the U.S. Government.

Although this information product, for the most part, is in the public domain, it also may contain copyrighted materials as noted in the text. Permission to reproduce copyrighted items must be secured from the copyright owner.

ISSN 2331-1258 (online) 


\section{Contents}

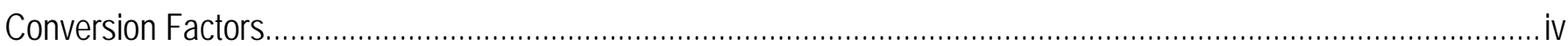

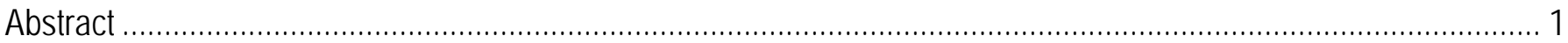

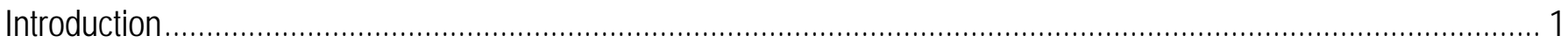

Methods

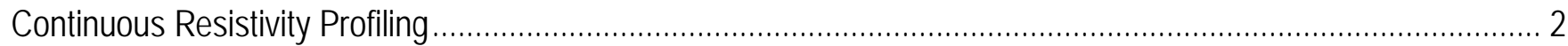

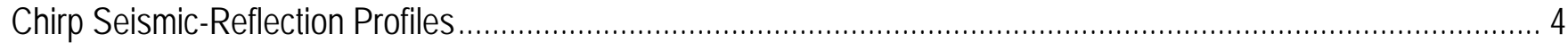

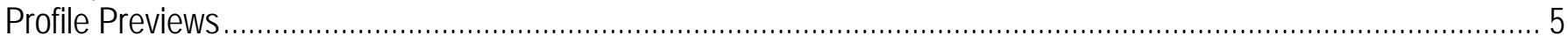

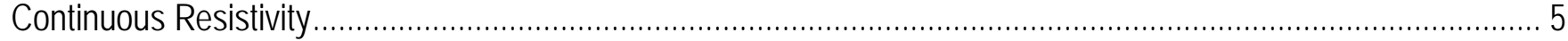

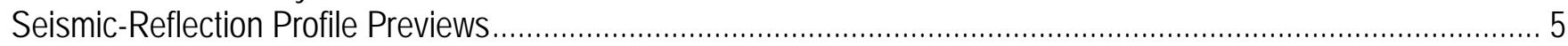

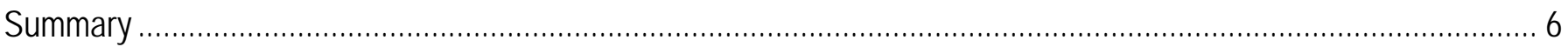

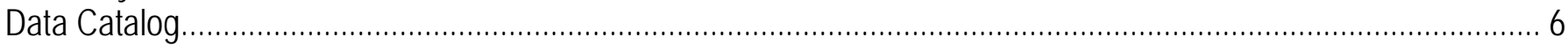

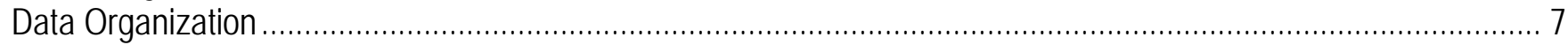

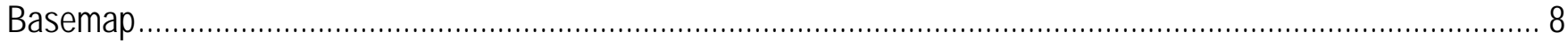

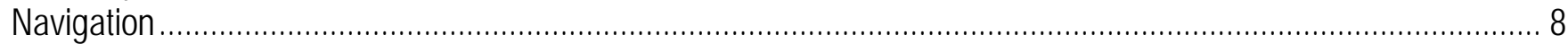

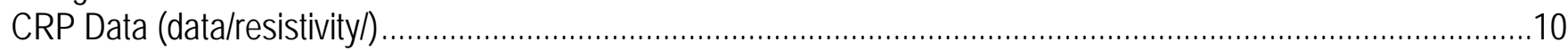

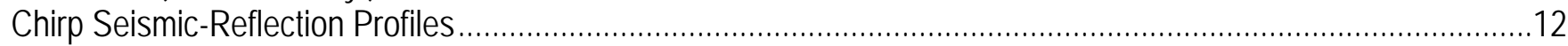

YSI 600 XLM Data

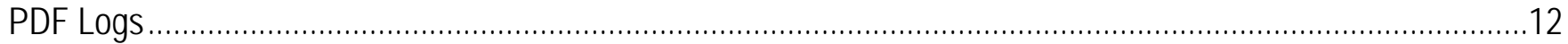

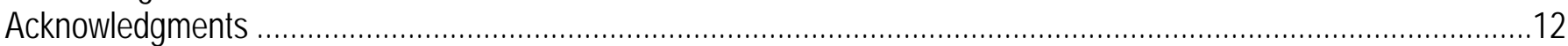

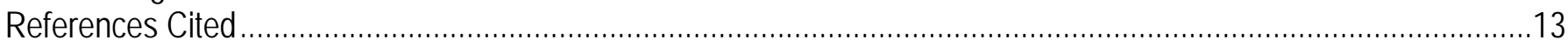

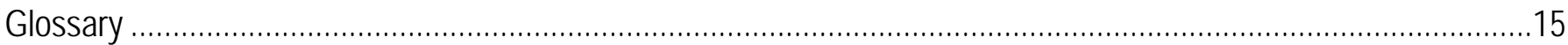

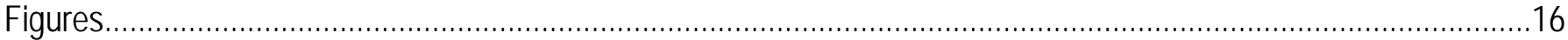

\section{Figures}

1. Location map showing the continuous resistivity profiling tracklines of the survey in Indian River Bay,

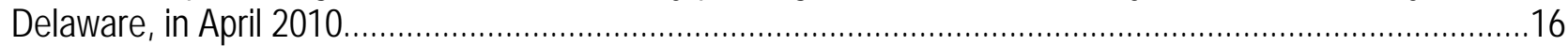

2. Photograph of the continuous resistivity profiling streamer deployed behind the survey boat ........................17

3. Photograph of the continuous resistivity profiling data acquisition system in a small survey boat ...................18

4. Photograph of the SB-424 chirp seismic transducer on the deck of a survey ship ......................................19

5. Oblique view of a horizontal slice through a three-dimensional model developed using continuous resistivity profiling data from the Indian River Bay collected in April 2010 .............................................................20

6. Perspective view from above of continuous resistivity processed data from the shore-parallel surveys collected off Holts Landing...........................................................................................................

7. Cross-section view of a vertical slice through a three-dimensional model of the continuous resistivity profile

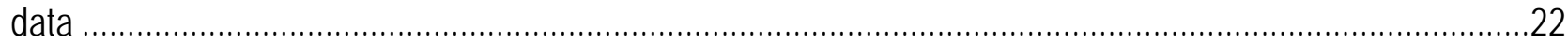

8. Chirp seismic-reflection profile collected near the Holts Landing shoreline along the same traverse ..............23

\section{Tables}

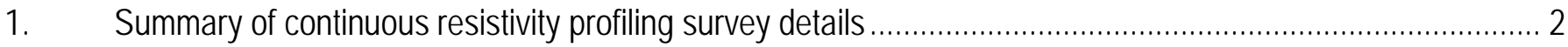

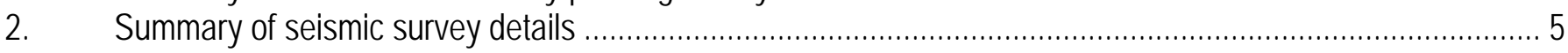




\section{Conversion Factors}

SI to Inch/Pound

\begin{tabular}{lll}
\hline \multicolumn{1}{c}{ Multiply } & By & \multicolumn{1}{c}{ To obtain } \\
\hline meter $(\mathrm{m})$ & Length & \\
kilometer $(\mathrm{km})$ & 3.281 & foot $(\mathrm{ft})$ \\
kilometer $(\mathrm{km})$ & 0.6214 & mile (mi) \\
meter $(\mathrm{m})$ & 0.5400 & mile, nautical (nmi) \\
\hline
\end{tabular}

Temperature in degrees Celsius $\left({ }^{\circ} \mathrm{C}\right)$ may be converted to degrees Fahrenheit $\left({ }^{\circ} \mathrm{F}\right)$ as follows:

$$
{ }^{\circ} \mathrm{F}=\left(1.8 x^{\circ} \mathrm{C}\right)+32
$$

Vertical coordinate information is referenced to the National Geodetic Vertical Datum of 1929 (NGVD29).

Horizontal coordinate information for newly collected data is referenced to the World Geodetic System 1984 (WGS84).

Basemap data from other sources is kept in its original horizontal datum and is referenced to North American Datum of 1983 (NAD83).

\section{Acronyms and Abbreviations}

$\begin{array}{ll}\text { AGI } & \text { Advanced Geosciences, Inc. (Austin, Texas) } \\ \text { CON } & \text { file extension for the AGI file format containing multiple water conductivity values used for data processing } \\ \text { CRP } & \text { continuous resistivity profiling } \\ \text { DEP } & \text { file extension for the AGI file format containing depth and temperature information } \\ \text { FAQ } & \text { frequently asked question } \\ \text { FGDC } & \text { Federal Geographic Data Committee } \\ \text { GeoTIFF } & \text { georeferenced tagged image file format } \\ \text { GIS } & \text { geographic information system } \\ \text { GPS } & \text { Global Positioning System; also a file extension for navigation acquired with the AGI system } \\ \text { HTML } & \text { hypertext markup language } \\ \text { INI } & \text { file extension for the text file containing the AGI Earthlmager 2D processing parameters for the CRP data } \\ \text { JPEG } & \text { Joint Photographic Experts Group } \\ \text { LLT } & \text { file extension for the AGI format file containing the latitude, longitude, and resistivity values of the processed CRP data } \\ \text { NAD83 } & \text { North American Datum of 1983 } \\ \text { PDF } & \text { Portable Document Format } \\ \text { R/V } & \text { research vessel } \\ \text { SEG-Y } & \text { Society of Exploration Geophysicists Y format for seismic data } \\ \text { STG } & \text { file extension for the AGI SuperSting resistivity data format } \\ \text { TIFF } & \text { Tagged Image File Format } \\ \text { USGS } & \text { U.S. Geological Survey } \\ \text { UTM } & \text { Universal Transverse Mercator } \\ \text { WGS84 } & \text { World Geodetic System of 1984 } \\ \text { XML } & \text { extensible markup language }\end{array}$




\title{
Continuous Resistivity Profiling and Seismic-Reflection Data Collected in April 2010 From Indian River Bay, Delaware
}

\author{
By V.A. Cross, ${ }^{1}$ J.F. Bratton, ${ }^{2}$ H.A. Michael,,${ }^{3}$ K.D. Kroeger,,${ }^{1}$ Adrian Green,${ }^{1}$ and Emile Bergeron ${ }^{1}$
}

\begin{abstract}
A geophysical survey to delineate the fresh-saline groundwater interface and associated subbottom sedimentary structures beneath Indian River Bay, Delaware, was carried out in April 2010. This included surveying at higher spatial resolution in the vicinity of a study site at Holts Landing, where intensive onshore and offshore studies were subsequently completed. The total length of continuous resistivity profiling (CRP) survey lines was 145 kilometers $(\mathrm{km})$, with $36 \mathrm{~km}$ of chirp seismic lines surveyed around the perimeter of the bay. Medium-resolution CRP surveying was performed using a 50-meter streamer in a baywide grid. Results of the surveying and data inversion showed the presence of many buried paleochannels beneath Indian River Bay that generally extended perpendicular from the shoreline in areas of modern tributaries, tidal creeks, and marshes. An especially wide and deep paleochannel system was imaged in the southeastern part of the bay near White Creek. Many paleochannels also had high-resistivity anomalies corresponding to low-salinity groundwater plumes associated with them, likely due to the presence of fine-grained estuarine mud and peats in the channel fills that act as submarine confining units. Where present, these units allow plumes of low-salinity groundwater that was recharged onshore to move beyond the shoreline, creating a complex fresh-saline groundwater interface in the subsurface. The properties of this interface are important considerations in construction of accurate coastal groundwater flow models. These models are required to help predict how nutrient-rich groundwater, recharged in agricultural watersheds such as this one, makes its way into coastal bays and impacts surface-water quality and estuarine ecosystems.
\end{abstract}

\section{Introduction}

Indian River Bay, Delaware, is located along the eastern shore of the Delmarva Peninsula. The bay and its watershed have been studied previously by numerous researchers because of its severe eutrophication issues and the identified role of submarine groundwater discharge as a major source of nitrogen delivery (Andres, 1992; Roy F. Weston, Inc., 1994; Delaware Department of Natural Resources and Environmental Control, 1995; Böhlke and Krantz, 2003; Bratton and others, 2004; Krantz and others, 2004; Manheim and others, 2004; Scudlark and others, 2005; Wang and others, 2008). A new multi-investigator project to measure and model elements of the Indian River Bay groundwater system began in 2009.

\footnotetext{
${ }^{1}$ U.S. Geological Survey

${ }^{2}$ National Oceanic and Atmospheric Administration

${ }^{3}$ University of Delaware
} 
From April 13 to 15, 2010, the initial phase of delineation of the fresh-saline groundwater interface and associated sub-bottom sedimentary structures beneath Indian River Bay was performed (fig. 1). The effort included surveying at higher spatial resolution in the vicinity of a study site at Holts Landing along the south-central shoreline of the bay, a location where offshore multi-level wells were later installed and seepage meter studies were performed. Some onshore wells had already been installed at that site by Delaware Geological Survey crews. The total length of continuous resistivity profiling (CRP) survey lines was 154 kilometers (km), with $33 \mathrm{~km}$ of coincident chirp seismic-reflection data collected around the perimeter of the bay on the first day of surveying. Medium-resolution CRP surveying was achieved using a 50-meter (m) streamer in a baywide grid (fig. 1). Underway salinity, temperature, and bathymetry measurements were also collected to permit processing and display of CRP data. The maximum tidal range in Indian River Bay during the survey was approximately $1 \mathrm{~m}$; the average water depth was less than $2 \mathrm{~m}$. This report was originally written as a web page report. Certain references in the text, such as file downloads and clickable maps, are only available from those web pages. Previews of continuous resistivity and seismic-reflection profiles are only available from the web pages.

\section{Methods}

Data collection and processing methods are described here for continuous resistivity profiling (CRP) data and chirp seismic-reflection data collected aboard the R/V Knob in Indian River Bay, Delaware. The CRP data were collected from April 13 to April 15, 2010 (Julian day 103 to Julian day 105), while chirp seismic-reflection data were only collected on April 13.

\section{Continuous Resistivity Profiling}

CRP data were collected in Indian River Bay in 2010 using methods similar to those described by Cross and others (2010, 2013). In this study, data were collected with a 50-m resistivity streamer for $145 \mathrm{~km}$. Table 1 summarizes the processed CRP data collection.

Table 1. Summary of continuous resistivity profiling survey details.

\begin{tabular}{ll}
\hline \multicolumn{1}{c}{ Parameter } & \multicolumn{1}{c}{ Survey detail } \\
\hline Tow-cable length & 50 meters \\
Electrode spacing & 5 meters \\
Source electrode type & graphite \\
Approximate depth penetration & $11-13$ meters \\
Cable configuration & dipole-dipole \\
Number of survey lines & 35 \\
Survey length & 145 kilometers \\
\hline
\end{tabular}

Data were collected using an Advanced Geosciences, Inc. (AGI) SuperSting R8 Marine resistivity system (figs. 2 and 3). The AGI cable used on this survey is a 50-m streamer with an 11electrode array with electrodes spaced $5 \mathrm{~m}$ apart. The two source electrodes are graphite, whereas the nine receiver electrodes are stainless steel. Foam flotation was attached to the cable between each electrode to keep the cable at or near the surface while allowing the electrodes to hang a little below the water surface, helping to keep the electrodes in the water in mildly choppy seas. The depth of penetration of this system is approximately 25 percent of the towed cable length. A dipole-dipole configuration was used for the data collection in which two fixed-current electrodes were assigned, and voltage potentials were then measured between electrode pairs in the remaining nine electrodes. 
Among other applications, CRP surveys are conducted to determine electrical resistivity of the subsurface in order to distinguish fresh from saline groundwater in shallow sedimentary units over large areas (Manheim and others, 2004; Cross and others, 2010, 2013). The initial values recorded by the system are measured apparent resistivity values. A two-dimensional (2D) resistivity model takes into account resistivity changes in the vertical and horizontal directions along a survey line, while assuming resistivity remains constant perpendicular to the survey line (Loke, 2000). The apparent resistivity data undergo an inversion process that produces a resistivity profile most consistent with the measured values. EarthImager 2D inversion software divides the subsurface into a number of rectangular blocks. The resistivity of each of these blocks is determined, creating an apparent resistivity pseudosection that is consistent with the measured apparent resistivity values. By constraining the model with the waterdepth profile, where water thickness (depth) and resistivity are known from field measurements, a more accurate subsurface resistivity profile can be generated. Processing parameters, such as the type of inversion process, number of iteration, and amount of roll-along data overlap, can be used to further constrain the modeling. The raw and processed data, including metadata compliant with Federal Geographic Data Committee (FGDC) standards, can be accessed through the Data Catalog page. The metadata files give full details on the parameters used to process the data.

The shipboard control and logging system used for the data collection of the resistivity streamer was an AGI SuperSting R8 Marine resistivity meter (fig. 3). Current was injected into the water/sediment system approximately every 3 seconds through the source electrode pair at the front end of the streamer, and eight apparent resistivity values representing eight depth levels were recorded for each current injection. A Lowrance LMS-480M Global Positioning System (GPS) with an LGD-2000 GPS antenna and a 200-kilohertz fathometer transducer with a temperature sensor were also attached to the system to acquire navigation and measure water depth.

At the end of each day of data acquisition, the CRP and navigation/depth data were downloaded from the SuperSting system to a laptop computer running AGI's Marine Log Manager software. The data were then transferred to a processing computer to check the quality of the navigation data and process the CRP data using AGI's Marine Log Manager and EarthImager 2D software packages. The Marine Log Manager software was used to merge the navigation file (file extension GPS) with the raw resistivity data (file extension STG), resulting in a linearized resistivity file (file extension STG) and a file containing the depth and temperature data when available (file extension DEP). These files are used as input to AGI's EarthImager 2D software for data processing.

The DEP files can be modified to include the water resistivity value measured at the time of surveying. Another instrument used during this survey, a YSI, Inc. 600 XLM data sonde, simultaneously collected surface-water conductivity and temperature data. These data were used to calculate the average water resistivity value over an individual CRP survey line. This information was then added to the DEP file used in processing the data. The average water resistivity value was appropriate for processing most of the survey lines. However, several survey lines extended from near the inlet in the east all the way to the fresher water sources in the west. These lines (L1F7, L4F1, L8F1, L9F3, L19F2, L20F2, and L38F1) were also processed using a water conductivity file (file extension CON) that incorporates the water resistivity variation over the length of the line. The resistivity values in the CON files were calculated from water conductivity values recorded with the YSI sensor based on the inverse relationship between the two measurements.

EarthImager 2D version 2.2.8 was used to process the data files (STG and DEP in all cases and STG and CON for some of the lines) using the supplied CRP saltwater processing parameters, which have minimum and maximum allowable resistance and voltages appropriate for the marine environment. The EarthImager 2D CRP module is specifically designed to process large amounts of 
continuous resistivity data, as are typically acquired during marine surveys. The strategy the software uses for data processing could be described as a "divide-and-conquer" method in which the long section of a single collection file is divided into many subsections. These subsections are individually inverted, and the processing culminates by assembling the individual sections into a single profile (Advanced Geosciences, Inc., 2005). The output files from all of these steps are saved into an individual folder. For the purposes of this report, the linearized STG and DEP files used as input for the processing were saved, as well as three file types generated during processing. When continuously measured water conductivity files were used, the linearized STG and CON files were saved, as well as three file types generated during processing. These three file types common to both methods of processing include:

- JPEG images of the complete resistivity profile. Both long (uncompressed, same horizontal scale) and short (compressed to fit on a single page, therefore having different horizontal scales) versions are available for each line.

- Text files of the processed resistivity data. These include XYZ files in which $\mathrm{X}=$ distance along line, $\mathrm{Y}=$ depth, and $\mathrm{Z}$ = resistivity value. Also included are LLT files, which contain longitude, latitude, depth, and resistivity values as well as UTM files, which contain easting, northing, depth, and resistivity values. The easting and northing values are in UTM, Zone 18, WGS84.

- A file with the INI extension contains the processing parameters used. This INI file can be loaded prior to subsequent file processing to ensure that the same parameters are used for all files or to verify the processing parameters used.

The JPEG images resulting from the EarthImager 2D processing were saved with the default color scale. This color scale ranges from blues to reds with reds representing the higher resistivity values corresponding to fresher (less saline) groundwater. The color scale within each image is maximized for the range of resistivity values from that survey line.

In addition, to more easily compare resistivity profiles, the MathWorks, Inc. MATLAB software was used to combine the XYZ and DEP files to generate JPEG images with a common color scale for all survey line files. Within these images, the polarity of the color scheme is the same as that of the EarthImager 2D JPEGs, in that the colors range from blue to red with reds indicating high resistivity values. MATLAB was also used to plot the data in an attempt to display the JPEG images with a common vertical and horizontal distance scale. Rounding errors in figure size scaling prevent exact reproducibility of scale in the horizontal direction for the images. Both the EarthImager 2D and the MATLAB JPEG images can be accessed from the Resistivity Profile Previews pages.

MATLAB was also used to remove the water-column resistivity data from the XYZ files based on the water depth data in the DEP data files. Both the DEP and XYZ data were interpolated within MATLAB in order to extract a resistivity value for the sediment/water interface. The interpolated value, along with the measured values within the sediment, was exported to the modified XYZ data file. All of the CRP lines were processed, and the results were combined into single shapefiles based on survey day. A separate shapefile exists for the CRP lines processed with a continuously measured water conductivity value. All of these files are available from the Data Catalog page.

Finally, a Visual Basic 6 program was written to combine the linearized STG file with the DEP file from each survey line to create a data file in RES2DINV format for users of that software package. These files are available from the Data Catalog page.

\section{Chirp Seismic-Reflection Profiles}

Chirp sub-bottom profiles were collected using an EdgeTech portable 3100 sub-bottom profiling system and SB-424 chirp towfish (fig. 4) operating at a 4- to 24-kilohertz pulse bandwidth and a 2millisecond pulse. The towfish containing the system transmitters and receiving hydrophones was 
deployed from a short line attached to a cleat on the starboard side of the boat and was towed approximately $0.5 \mathrm{~m}$ below the water surface. The system was on a short line attached to a cleat. EdgeTech Discover acquisition software was used to record the data in SEG-Y format (Norris and Faichney, 2002). Navigation was supplied by a Lowrance GPS system with the antenna mounted topside on a pole coincident with the tow position of the chirp transducer. The navigation was written to the header of the SEG-Y files in arc-second format. Vertical draft offset corrections were not applied to the raw data. The system fired four to six times per second with a trace length of 133 milliseconds, a sample interval of 23 microseconds, and 5,788 samples per trace. Seismic Unix (Stockwell and Cohen, 2008) was used to read the SEG-Y files, apply an automatic gain control, and create JPEG plots of the trace data.

Due to problems with the acquisition system, seismic-reflection data were only collected on the first day of surveying. JPEG images of these profiles can be accessed from the Seismic Profiles Previews page. These files, as well as the SEG-Y data files, are also available from the Data Catalog page.

Table 2. Summary of seismic survey details.

\begin{tabular}{ll}
\hline \multicolumn{1}{c}{ Parameter } & \multicolumn{1}{c}{ Survey detail } \\
\hline System & EdgeTech 424 \\
Operating frequency & 4 to 24 kilohertz \\
Fire rate & 4 to 6 times per second \\
Trace length & 133 milliseconds \\
Number of survey lines & 16 \\
Survey length & 36 kilometers \\
\hline
\end{tabular}

\section{Profile Previews}

Both the continuous resistivity profiling (CRP) and chirp seismic-reflection data are presented as JPEG profiles. These profiles are available for viewing from their respective profile preview pages only in the HTML pages (Continuous Resistivity and Seismic-reflection) and are available for download from the Data Catalog page in the HTML pages. The profile preview pages provide interactive maps showing the spatial orientation and location of the profiles and thumbnail JPEG images of the profiles. The thumbnails on the profile preview pages provide the user with a quick visual representation of the data collected and links to larger versions of the profiles. The line numbers in the interactive maps provide links to the images of the profiles.

\section{Continuous Resistivity}

The CRP profile previews are organized by date of acquisition. These profiles are available for viewing from their respective HTML pages and are available for download from the Data Catalog page. The thumbnails on the profile preview pages provide a quick visual representation of the data collected. In addition, these pages provide links to large versions of the profiles, as well as a clickable trackline map that shows the spatial orientation and location of the profiles.

\section{Seismic-Reflection Profile Previews}

The HTML page contains the previews of the chirp seismic-reflection profiles. The trackline map on that page is a "clickable" map. By clicking on a line name, a new window will open with the full-size JPEG image from that particular line segment. All of these lines were collected on April 13, 2010, which corresponds to Julian day 103. The $\mathrm{x}$ axis of the images represents the seismic shot 
number. The y axis of the images is the two-way travel time in seconds, which is the time for the transmitted signal to be reflected back to the receiver.

\section{Summary}

Results of the continuous resistivity profiling and concurrent chirp seismic surveys and data inversion show the presence of many buried paleochannels beneath Indian River Bay that generally extend perpendicular from the shoreline in areas adjacent to modern tributaries, tidal creeks, and marshes (fig. 5). An especially wide and deep paleochannel system was imaged in the southeastern part of the bay near White Creek. Many (but not all) paleochannels also had high resistivity anomalies (lowsalinity groundwater plumes) associated with them. One such association near Holts Landing is shown in figures 6-8. Results of additional seismic and electrical resistivity surveys performed by the University of Toledo are described separately (Banaszak, 2011). Subsequent intensive sampling, measurements using seepage meters, installation of offshore and onshore wells, and modeling were performed in 2010 through 2012 (Fernandez and others, 2011; Michael and others 2011a,b; Russoniello and others, 2013). Results were generally consistent with geophysical data reported here.

\section{Data Catalog}

This report contains geographic information system (GIS) data in vector and raster formats. The vector data are available in Esri shapefile format. Shapefiles generally include .shp, .shx, and .dbf files at a minimum. All these data files include the .prj files that contain the dataset projection information. The raster data are available in Esri binary grid format and GeoTIFF format. For the sake of brevity, only the filename prefix has been included in the column 'Filename' listed below. Clicking on the image in the 'View' column of GIS-compatible data will display a thumbnail image of the dataset. The files necessary to load each dataset into a compatible GIS have been compressed into a single zip file, along with Federal Geographic Data Committee (FGDC)-compliant metadata in text, FAQ, HTML and XML format. A second XML metadata format generated and viewable by ArcCatalog is also included in the compressed zip file. In addition, the FGDC-compliant text, FAQ, and HTML versions of the metadata for each dataset have links provided in the links in the 'Metadata' column listed below. The data files can be downloaded directly from the 'Download link and file size' portion of the tables.

In addition to the GIS data, this report also contains CRP and chirp seismic-reflection data. The CRP data are available in both raw and processed formats. Each line of data acquisition comprises multiple files, as described in the Methods section of this report. For this reason, these data are organized by day of collection and are available as compressed zip files for each day of data collection. The seismic-reflection data are available as JPEG images of the profiles and in the SEG-Y data format. All of the JPEG images of the seismic profiles are available for download in a single compressed zip file. The SEG-Y format files are available from the link to the folder where these files reside (data/seismics/segy/) and can be downloaded individually.

The CRP tracklines as well as the seismic-reflection profile tracklines can be hyperlinked to associated images within ArcGIS. Within the CRP tracklines shapefile, two text attributes, "hotlink" and "hlink2", can be utilized to hyperlink to the JPEG images of the resistivity profiles. The "hotlink" attribute points to the MATLAB JPEG image, and the "hlink2" attribute points to the long version of the EarthImager 2D JPEG image. Within the seismic-reflection tracklines shapefile, the attribute "hotlink" points to the JPEG image of the seismic-reflection profile. The metadata for each trackline shapefile gives further instruction on using the hyperlink feature. 
Additional data included in the tables below are the HYPACK navigation files (both raw and converted to shapefile format), the YSI 600 XLM surface water data, and the handwritten data acquisition logs converted into the Portable Document Format (PDF). These files along with the FGDCcompliant metadata are available from the tables in compressed zip files.

To download the data from the table below, use the mouse to right-click on the link in the 'Download...' column, then select 'Save Target As...' to save the compressed zip file to the local hard drive. Microsoft Windows, since the Millennium Edition, supports extracting zip files natively without additional third party software. Simply double-click on the file to begin the extraction wizard. In cases where a utility program to uncompress files is needed and not currently installed on the local system, 7zip (http://www.7-zip.org/) provides an open source utility. These files were compressed with WinZip version 9.0.

\section{Data Organization}

The data are organized in folders on the website. Data layers can be downloaded individually using the table below. If the website folder structure for the data is replicated on a computer, the provided ArcMap 9.2 map document, ofr2011-1039_IndianRiverBay.mxd, can be used to display the data layers. The ArcMap document was created with the "Save As" command in ArcMap 9.3.1 in order to generate the 9.2 version document.

data-Top-level directory for all the data.

ofr2011-1039_IndianRiverBay.mxd-ArcMap 9.2 map document with the GIS compatible data loaded in the table of contents.

basemap-Folder containing the coastline file and color-coded bathymetry GeoTIFF images.

bathy-Folder containing the Esri binary grid of the bathymetry.

navigation-Folder containing all the data related to navigation.

hypack-Folder containing the HYPACK navigation data.

jd103 - Folder containing the raw HYPACK navigation data from Julian day 103 (April 13, 2010).

jd104-Folder containing the raw HYPACK navigation data from Julian day 104 (April 14, 2010).

jd105-Folder containing the raw HYPACK navigation data from Julian day 105 (April 15, 2010).

processed-Folder containing the parsed HYPACK navigation data in shapefile format.

resistivity_-Folder containing the resistivity navigation in shapefile format.

seismics-Folder containing the seismic trackline and shot point navigation in shapefile format.

resistivity_Folder containing the resistivity data.

proc_resis_-Folder containing the processed resistivity data. The data are contained in sub-folders based on day of acquisition.

raw_resis-Folder containing the processed resistivity data. The data are contained in sub-folders based on day of acquisition.

res2dinv_format_-Folder containing the resistivity data in RES2DINV format. The data are contained in sub-folders based on day of acquisition.

shapefile-Folder containing the processed resistivity data in shapefile format. seismics-Folder containing the seismic-reflection data. 
jpegs-Folder containing the JPEG images of the seismic-reflection profiles. These images can be "hotlinked" to the seismic navigation tracklines.

segy-Folder containing the SEG-Y format of the seismic-reflection profiles. survey_logs_-Folder containing the PDF document of the data acquisition logs. ysi_sensor-Folder containing the YSI 600 XLM data in Excel and shapefile format.

\section{Basemap (data/basemap/)}

\begin{tabular}{|c|c|c|c|c|}
\hline Filename & Description & View & Metadata & Download \\
\hline nos80k_northeast & $\begin{array}{l}\text { Polyline shapefile from the National Oceanic and } \\
\text { Atmospheric Administration of the shoreline in the } \\
\text { Northeast United States. (Geographic, NAD83) }\end{array}$ & & $\begin{array}{l}\text { HTML } \\
\text { FAQ } \\
\text { TEXT }\end{array}$ & $\begin{array}{l}\text { nos80k_northeast.zip } \\
8.2 \mathrm{MB}\end{array}$ \\
\hline irb_bathy & $\begin{array}{l}\text { Esri binary grid of Indian River Bay bathymetry } \\
\text { generated from fathometer data. (UTM, Zone 18, } \\
\text { WGS84) }\end{array}$ & & $\begin{array}{l}\text { HTML } \\
\text { FAQ } \\
\text { TEXT }\end{array}$ & $\begin{array}{l}\text { irb_bathy.zip } \\
0.26 \mathrm{MB}\end{array}$ \\
\hline irb_bathyimg & $\begin{array}{l}\text { Color GeoTIFF image of Indian River Bay } \\
\text { bathymetry generated from fathometer data. (UTM, } \\
\text { Zone 18, WGS84) }\end{array}$ & & $\begin{array}{l}\text { HTML } \\
\text { FAQ } \\
\text { TEXT }\end{array}$ & $\begin{array}{l}\text { irb_bathyimg.zip } \\
0.06 \mathrm{MB}\end{array}$ \\
\hline irb_bathy_geo & $\begin{array}{l}\text { Color GeoTIFF image of Indian River Bay } \\
\text { bathymetry generated from fathometer data. } \\
\text { (Geographic, WGS84) }\end{array}$ & & $\begin{array}{l}\text { HTML } \\
\text { FAQ } \\
\text { TEXT }\end{array}$ & $\begin{array}{l}\text { irb_bathy_geo.zip } \\
1.2 \mathrm{MB}\end{array}$ \\
\hline
\end{tabular}

\section{Navigation (data/navigation/)}

These data are organized into three subdirectories based on the instrument associated with the navigation.

hypack - this folder contains the navigation recorded by the HYPACK navigation system (data/navigation/hypack/).

resistivity-this folder contains the navigation recorded by the Lowrance GPS that is part of the CRP acquisition system (data/navigation/resistivity/).

seismics - this folder contains the navigation used with the seismic-reflection profiles (data/navigation/seismics/). 


\begin{tabular}{|c|c|c|c|c|}
\hline Filename & Description & View & Metadata & Download \\
\hline jd103hypack & $\begin{array}{l}\text { Point shapefile of the parsed HYPACK } \\
\text { navigation from Julian day } 103 \text { (April 13, } \\
\text { 2010). (Geographic, WGS84) }\end{array}$ & & $\begin{array}{l}\text { HTML } \\
\text { FAQ } \\
\text { TEXT }\end{array}$ & $\begin{array}{l}\text { jd103hypack.zip } \\
0.54 \mathrm{MB}\end{array}$ \\
\hline jd104hypack & $\begin{array}{l}\text { Point shapefile of the parsed HYPACK } \\
\text { navigation from Julian day } 104 \text { (April 14, } \\
\text { 2010). (Geographic, WGS84) }\end{array}$ & & $\begin{array}{l}\text { HTML } \\
\text { FAQ } \\
\text { TEXT }\end{array}$ & $\begin{array}{l}\text { jd104hypack.zip } \\
0.68 \text { MB }\end{array}$ \\
\hline jd105hypack & $\begin{array}{l}\text { Point shapefile of the parsed HYPACK } \\
\text { navigation from Julian day } 105 \text { (April 15, } \\
\text { 2010). (Geographic, WGS84) }\end{array}$ & & $\begin{array}{l}H T M L \\
F A Q \\
T E X T\end{array}$ & $\begin{array}{l}\text { jd105hypack.zip } \\
0.67 \text { MB }\end{array}$ \\
\hline hypacknav_raw & $\begin{array}{l}\text { Text files of the raw HYPACK navigation } \\
\text { collected during Field Activity 2010-006- } \\
\text { FA. }\end{array}$ & & $\begin{array}{l}\text { HTML } \\
\text { FAQ } \\
\text { TEXT }\end{array}$ & $\begin{array}{l}\text { hypacknav_raw.zip } \\
6.4 \mathrm{MB}\end{array}$ \\
\hline jd103gps_bestdepth & $\begin{array}{l}\text { Point shapefile of all the navigation fixes } \\
\text { acquired with the CRP data on Julian day } \\
103 \text { (April 13, 2010) with additional } \\
\text { bathymetry data processing. (Geographic, } \\
\text { WGS84) }\end{array}$ & & $\begin{array}{l}H T M L \\
F A Q \\
T E X T\end{array}$ & $\begin{array}{l}\text { jd103gps_bestdepth.zip } \\
0.29 \mathrm{MB}\end{array}$ \\
\hline jd103gps_lines_splits & $\begin{array}{l}\text { Polyline shapefile of all the navigation fixes } \\
\text { acquired with the CRP data on Julian day } \\
103 \text { (April 13, 2010). Original polylines, as } \\
\text { well as polylines split to correspond to } \\
\text { processed sections, are included. } \\
\text { (Geographic, WGS84) }\end{array}$ & & $\begin{array}{l}H T M L \\
F A Q \\
T E X T\end{array}$ & $\begin{array}{l}\text { jd103gps_lines_splits.zip } \\
0.08 \mathrm{MB}\end{array}$ \\
\hline jd104gps_bestdepth & $\begin{array}{l}\text { Point shapefile of all the navigation fixes } \\
\text { acquired with the CRP data on Julian day } \\
104 \text { (April 14, 2010) with additional } \\
\text { bathymetry data processing. (Geographic, } \\
\text { WGS84) }\end{array}$ & & $\begin{array}{l}\text { HTML } \\
\text { FAQ } \\
\text { TEXT }\end{array}$ & $\begin{array}{l}\text { jd104gps_bestdepth.zip } \\
0.4 \mathrm{MB}\end{array}$ \\
\hline jd104gps_lines & $\begin{array}{l}\text { Polyline shapefile of all the navigation fixes } \\
\text { acquired with the CRP data on Julian day } \\
104 \text { (April 14, 2010). (Geographic, WGS84) }\end{array}$ & & $\begin{array}{l}\text { HTML } \\
\text { FAQ } \\
\text { TEXT }\end{array}$ & $\begin{array}{l}\text { jd104gps_lines.zip } \\
0.09 \text { MB }\end{array}$ \\
\hline jd105gps_bestdepth & $\begin{array}{l}\text { Point shapefile of all the navigation fixes } \\
\text { acquired with the CRP data on Julian day } \\
105 \text { (April 14, 2010) with additional } \\
\text { bathymetry data processing. (Geographic, } \\
\text { WGS84) }\end{array}$ & & $\begin{array}{l}H T M L \\
F A Q \\
T E X T\end{array}$ & $\begin{array}{l}\text { jd105gps_bestdepth.zip } \\
0.47 \text { MB }\end{array}$ \\
\hline jd105gps_lines_splits & $\begin{array}{l}\text { Polyline shapefile of all the navigation fixes } \\
\text { acquired with the CRP data on Julian day } \\
105 \text { (April 15, 2010). Original polylines, as } \\
\text { well as polylines split to correspond to } \\
\text { processed sections are included. }\end{array}$ & & $\begin{array}{l}\text { HTML } \\
\text { FAQ } \\
\text { TEXT }\end{array}$ & $\begin{array}{l}\text { jd105gps_lines_splits.zip } \\
0.11 \mathrm{MB}\end{array}$ \\
\hline
\end{tabular}




\begin{tabular}{|c|c|c|c|c|}
\hline Filename & Description & View & Metadata & Download \\
\hline & (Geographic, WGS84) & & & \\
\hline ir_seisnav & $\begin{array}{l}\text { Point shapefile of all the unique seismic shot } \\
\text { point navigation collected during the cruise. } \\
\text { (Geographic, WGS84) }\end{array}$ & & $\begin{array}{l}\text { HTML } \\
\text { FAQ } \\
\text { TEXT }\end{array}$ & $\begin{array}{l}\text { ir_seisnav.zip } \\
0.49 \mathrm{MB}\end{array}$ \\
\hline ir_100shot_sort & $\begin{array}{l}\text { Point shapefile of the } 100 \text { shot interval } \\
\text { seismic navigation. (Geographic, WGS84) }\end{array}$ & & $\begin{array}{l}\text { HTML } \\
\text { FAQ } \\
\text { TEXT }\end{array}$ & $\begin{array}{l}\text { ir_100shot_sort.zip } \\
0.08 \mathrm{MB}\end{array}$ \\
\hline ir_Routes_Calib & $\begin{array}{l}\text { Polyline-M shapefile of all the seismic } \\
\text { navigation calibrated to the shot point } \\
\text { navigation. (Geographic, WGS84) }\end{array}$ & & $\begin{array}{l}\text { HTML } \\
\text { FAQ } \\
\text { TEXT }\end{array}$ & $\begin{array}{l}\text { ir_Routes_Calib.zip } \\
0.21 \mathrm{MB}\end{array}$ \\
\hline
\end{tabular}

\section{CRP Data (data/resistivityl)}

Raw CRP data (data/resistivity/raw_resis/): Compressed zip file contains the raw resistivity data collected by the AGI SuperSting system.

Processed CRP data (data/resistivity/proc_resis/): Compressed file includes the linearized STG file and accompanying DEP file, the EarthImager processed files that used the measured water resistivity value when possible, and the MATLAB-generated profile images. Additionally, one folder contains the linearized STG file and accompanying DEP file and a CON file containing the continuous water resistivity values as well as the EarthImager processing results and MATLAB-generated profile images.

Processed CRP data (data/resistivity/shapefile/): Compressed file includes processed CRP data below the sediment water interface in shapefile format.

\section{RES2DINV format CRP data (data/resistivity/res2dinv_format): WinZip file includes the} RES2DINV format files based on the linearized STG and DEP files.

See the metadata for more details on the individual file types and how they were generated.

\begin{tabular}{|c|c|c|c|}
\hline Filename & Description & Metadata & Download \\
\hline apr12_raw & $\begin{array}{l}\text { WinZip file containing the raw CRP data from April 12, 2010, in } \\
\text { Indian River Bay. }\end{array}$ & $\begin{array}{l}\text { HTML } \\
F A Q \\
\text { TEXT }\end{array}$ & $\begin{array}{l}\text { apr12_raw.zip } \\
0.05 \mathrm{MB}\end{array}$ \\
\hline apr13_raw & $\begin{array}{l}\text { WinZip file containing the raw CRP data from April 13, 2010, in } \\
\text { Indian River Bay. }\end{array}$ & $\begin{array}{l}\text { HTML } \\
F A Q \\
T E X T\end{array}$ & $\begin{array}{l}\text { apr13_raw.zip } \\
0.78 \mathrm{MB}\end{array}$ \\
\hline apr14_raw & $\begin{array}{l}\text { WinZip file containing the raw CRP data from April 14, 2010, in } \\
\text { Indian River Bay. }\end{array}$ & $\begin{array}{l}\text { HTML } \\
F A Q \\
\text { TEXT }\end{array}$ & $\begin{array}{l}\text { apr14_raw.zip } \\
1.02 \mathrm{MB}\end{array}$ \\
\hline apr15_raw & $\begin{array}{l}\text { WinZip file containing the raw CRP data from April 15, 2010, in } \\
\text { Indian River Bay. }\end{array}$ & $\begin{array}{l}\text { HTML } \\
F A Q \\
\text { TEXT }\end{array}$ & $\begin{array}{l}\text { apr15_raw.zip } \\
1.29 \mathrm{MB}\end{array}$ \\
\hline
\end{tabular}




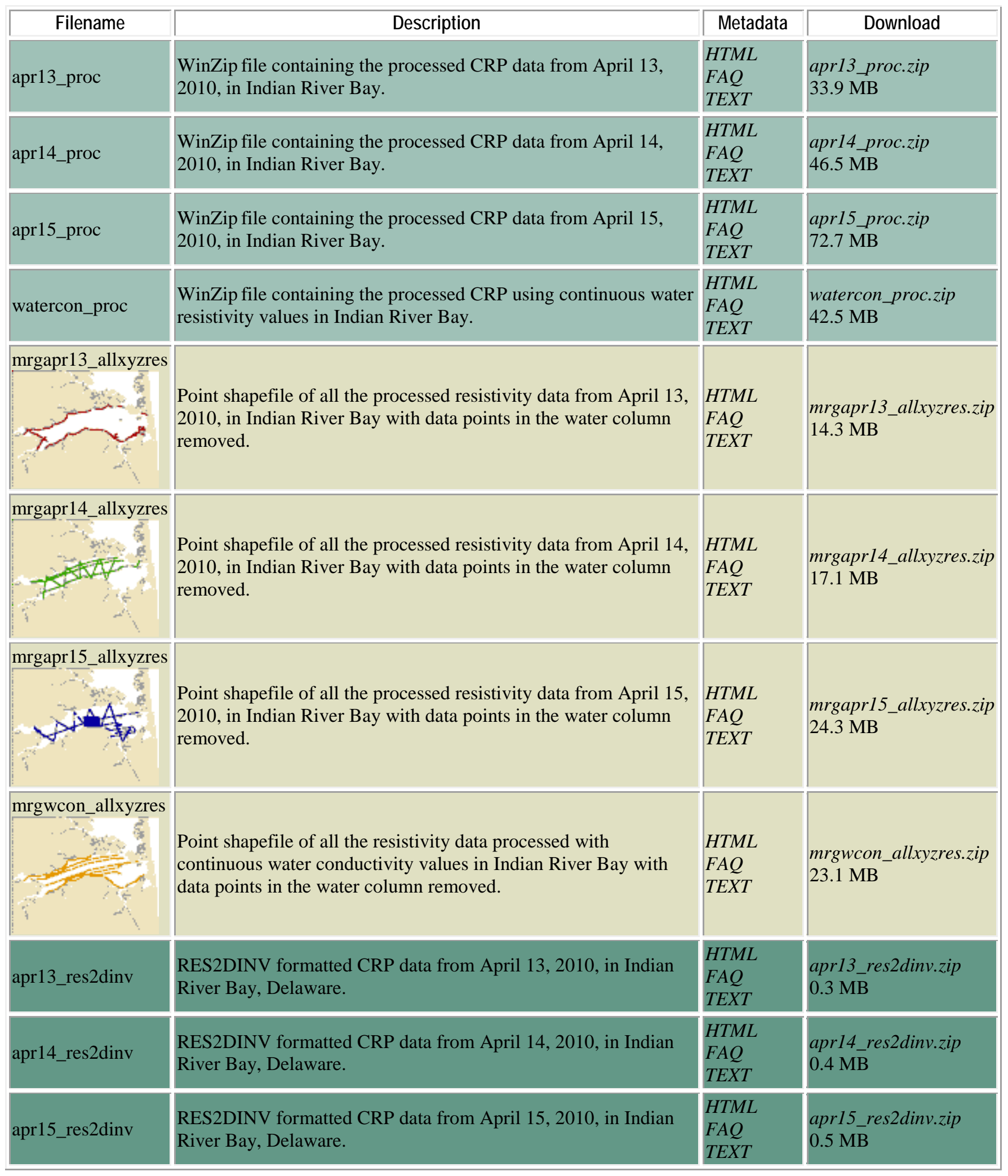




\section{Chirp Seismic-Reflection Profiles (data/seismics/)}

\begin{tabular}{|c|c|c|c|}
\hline Filename & Description & Metadata & Download \\
\hline seismic_jpegs & $\begin{array}{l}\text { Compressed zip file of all the seismic-reflection profiles in the } \\
\text { JPEG image format. }\end{array}$ & $\begin{array}{l}\text { HTML } \\
\text { FAQ } \\
\text { TEXT }\end{array}$ & $\begin{array}{l}\text { seismic_jpegs.zip } \\
19.9 \mathrm{MB}\end{array}$ \\
\hline seismic_segy & $\begin{array}{l}\text { SEG-Y format of the chirp seismic-reflection data. The top link is } \\
\text { to the folder containing the data. The second link is to a compressed } \\
\text { zip file of the metadata. }\end{array}$ & $\begin{array}{l}\text { HTML } \\
\text { FAQ } \\
\text { TEXT }\end{array}$ & $\begin{array}{l}\text { data/seismics/segy/ } \\
10 \mathrm{MB} \text { to } 177 \mathrm{MB} \\
\text { seismic_segymeta.zip } \\
0.02 \mathrm{MB}\end{array}$ \\
\hline
\end{tabular}

YSI 600 XLM Data (data/ysi_sensorl)

\begin{tabular}{|l|l|l|l|l|}
\hline \multicolumn{1}{|c|}{ Filename } & \multicolumn{1}{|c|}{ Description } & \multicolumn{1}{|c|}{ Metadata } & Download \\
\hline \multirow{2}{*}{ IndianRivBayYSI } & $\begin{array}{l}\text { Excel 2003 spreadsheet containing the YSI 600 XLM data collected } \\
\text { in Indian River Bay in April 2010. }\end{array}$ & $\begin{array}{l}\text { HTML } \\
\text { FAQ } \\
\text { TEXT }\end{array}$ & $\begin{array}{l}\text { IndianRivBayYSI.zip } \\
0.01 \text { MB }\end{array}$ \\
\hline ysi_Merge & $\begin{array}{l}\text { Point shapefile of filtered YSI 600 data that have been assessed to be } \\
\text { valid values for use with the CRP data. (Geographic, WGS84) }\end{array}$ & $\begin{array}{l}\text { HTML } \\
\text { FAQ } \\
\text { TEXT }\end{array}$ & $\begin{array}{l}\text { TSi_Merge.zip } \\
\text { TE.07 MB }\end{array}$ \\
\hline
\end{tabular}

PDF Logs (data/survey_log/)

\begin{tabular}{|l|l|l|l|}
\hline \multicolumn{1}{|c|}{ Filename } & \multicolumn{1}{|c|}{ Description } & \multicolumn{1}{c|}{ Metadata } & \multicolumn{1}{c|}{ Download } \\
\hline cruise2010-006_logs & PDF file of the data acquisition logs. & HTML & FAQ \\
& & Fruise2010-006_logs.zip \\
& & TEXT & 1.9 MB \\
\hline
\end{tabular}

\section{Acknowledgments}

Joel Banaszak and David Krantz (both from the University of Toledo), along with Holly Michael, Chris Russionello and Cristina Fernandez (of the University of Delaware) assisted with field work. Adrian Green and Emile Bergeron of the U.S. Geological Survey also assisted with field work. Staff from the Delaware Department of Natural Resources and Environmental Control Holts Landing State Park and Indian River Marina at Delaware Seashore State Park supported survey vessel operations. The Delaware Center for the Inland Bays hosted a project kickoff meeting. Funding was provided by the U.S. Geological Survey Coastal and Marine Geology Program and the U.S. National Science Foundation Hydrologic Sciences Program (Award \#0911805). Seth Ackerman, Dave Foster, and Jeff Obelcz (of the U.S. Geological Survey) provided helpful comments on drafts of the report. 


\section{References Cited}

Advanced Geosciences, Inc., 2005, Instruction manual for EarthImager 2D, version 1.9.0, Resistivity and IP inversion software: Advanced Geosciences, Inc., 134 p., accessed at http://www.agiusa.com/. [Registration required.]

Andres, A.S., 1992, Estimate of nitrate flux to Rehoboth and Indian River Bays, Delaware, through direct discharge of ground water: Delaware Geological Survey Open-File Report No. 35, 39 p. (Also available at $h$ ttp://www.dgs.udel.edu/sites/dgs.udel.edu/files/publications/OFR35.pdf.)

Banaszak, J.F., 2011, Hydrostratigraphic framework for the surficial aquifer in the Indian River Bay, Delaware, Watershed: Master of Science Thesis, University of Toledo, $220 \mathrm{p}$.

Böhlke, J.K., and Krantz, D.E., 2003, Isotope geochemistry and chronology of offshore ground water beneath Indian River Bay, Delaware: U.S. Geological Survey Water-Resources Investigations Report 03-4192, 37 p. (Also available at $h t t p: / / p u b s . u s g s . g o v / w r i / w r i 034192 /$.

Bratton, J.F., Böhlke, J.K., Manheim, F.T., and Krantz, D.E., 2004, Ground water beneath coastal bays of the Delmarva Peninsula—Ages and nutrients: Ground Water, v. 42, no. 7, p. 1021-1034. (Also available at $h$ ttp://onlinelibrary.wiley.com/doi/10.1111/j.1745-6584.2004.tb02641.x/abstract.)

Cross, V.A., Foster, D.S., and Bratton, J.F., 2010, Continuous resistivity profiling and seismic-reflection data collected in 2006 from the Potomac River Estuary, Virginia and Maryland: U.S. Geological Survey Open-File Report 2009-1151, available at $h$ ttp://pubs.usgs.gov/of/2009/1151/.

Cross, V.A., Bratton, J.F., Kroeger, K.D., Crusius, J., and Worley, C.W., 2013, Continuous resistivity profiling data from Great South Bay, Long Island, New York: U.S. Geological Survey Open-File Report 2011-1040, available at http://pubs.usgs.gov/of/2011/1040/.

Delaware Department of Natural Resources and Environmental Control, 1995, A comprehensive conservation and management plan for Delaware's inland bays: Delaware Department of Natural Resources and Environmental Control, Dover, Del. (Also available at $h t t p: / / w w w . i n l a n d b a y s . o r g / w p-$ content/documents/comp_conservation_plan_for_the_inland_bays.pdf.)

Fernandez, Cristina, Kroeger, K.D., Bratton, J.F., Russoniello, C.J., Musetto, Andrew, Andres, A.S., and Michael, H.A, 2011, Porewater salinity distribution and geochemical characterization beneath Indian River Bay, Delaware: National Ground Water Association Ground Water Summit, May 1-5, 2011, Baltimore, Md.

Krantz, D.E., Manheim, F.T., Bratton, J.F., and Phelan, D.J., 2004, Hydrogeologic setting and ground water flow beneath a section of Indian River Bay, Delaware: Ground Water, v. 42, p. 1035-1051. (Also available at $h$ ttp://onlinelibrary.wiley.com/doi/10.1111/j.1745-6584.2004.tb02642.x/abstract.)

Loke, J.H., 2000, Electrical imaging surveys for environmental and engineering studies-A practical guide to 2D and 3D surveys: Penang, Malaysia, University Sains Malaysia, $67 \mathrm{p}$.

Manheim, F.T., Krantz, D.E., and Bratton, J.F., 2004, Studying ground water under Delmarva coastal bays using electrical resistivity: Ground Water, v. 42, no. 7, p. 1052-1068. (Also available at http://onlinelibrary.wiley.com/doi/10.1111/j.1745-6584.2004.tb02643.x/abstract.)

Michael, H.A., Russoniello, C.J., Fernandez, Cristina, Musetto, Andrew, Myers, Kevin, Bratton, J.F., Andres, A.S., Krantz, D.E., Banaszak, J.F., Kroeger, K.D., and Konikow, L.F., 2011a, Spatial patterns in subsurface salinity and submarine groundwater discharge into Indian River Bay, Delaware: National Ground Water Association Ground Water Summit, May 1-5, 2011, Baltimore, Md. Michael, H.A., Fernandez, Cristina, Russoniello, C.J., Andres, A.S., Kroeger, K.D., Krantz, D.E., Banaszak, J.F., Musetto, Andrew, Myers, Kevin, Konikow, L.F., and Bratton, J.F., 2011b, Geologic and hydrologic control of porewater chemistry and submarine groundwater discharge into Indian 
River Bay, Delaware: Goldschmidt 2011 Conference, Prague, Czech Republic, August 14-19, p. 1462.

Norris, M.W., and Faichney, A.K., eds., 2002, SEG Y rev 1 data exchange format, SEG Technical Standards Committee, release 1.0: Tulsa, Oklahoma, Society of Exploration Geophysicists, May 2002, 45 p. (Also available at http://www.seg.org/documents/10161/77915/seg_y_rev1.pdf.)

Russoniello, C.J., Fernandez, Cristina, Bratton, J.F., Banaszak, J.F., Krantz, D.E., Andrews, A.S., Konikow, L.F., and Michael, H.A., 2013, Geologic effects on groundwater salinity and discharge into an estuary: Journal of Hydrology.

Scudlark, J.R., Jennings, J.A., Roadman, M.J., Savidge, K.B., Ullman, W.J., 2005, Atmospheric nitrogen inputs to the Delaware Inland Bays-The role of ammonia: Environmental Pollution, v. 135, no. 3, p. 433-443. (Also available at http://www.sciencedirect.com/science/article/pii/S026974910400466X.)

Stockwell, J.W., Jr., and Cohen, J.K., 2008, The new SU user’s manual (version 4.0): Golden, Colorado, Center for Wave Phenomena-Colorado School of Mines, 153 p.

Wang, L.T., McKenna, T.E., and DeLiberty, T.L., 2008, Locating ground-water discharge areas in Rehoboth and Indian River Bays and Indian River, Delaware using Landsat 7 imagery: Delaware Geological Survey, Report of Investigations No. 74, 11 p. (Also available at http://landsat.gsfc.nasa.gov/pdf_archive/UD_040708-ri74.pdf.) 


\section{Glossary}

anomalies Unusually high or low values or patterns.

chirp seismic A seismic system that transmits a linearly swept signal (from low to high), wide band frequency modulated (FM) pulse in the water. When the reflections are received they are processed to remove the FM carrier signal.

conductivity The ability of a material or mixture to carry an electrical current.

dipole A pair of positive and negative charges separated by a small distance.

draft A nautical term describing the depth of an object on a ship below the water surface, often the bottom or keel of the ship.

eutrophication An increase in the concentration of dissolved nutrients in a water body that increases growth or algae, often to a harmful degree and often caused by human influences.

geophysical Relating to the application of surface or borehole measurements, often using sound or electrical energy, to determine or infer the subsurface properties of land and water bodies.

groundwater Water located beneath the ground surface or sediment surface in pore spaces and

fractures.

interpolated Interpreted conditions between locations of measured data.

inversion The process of working backwards from measured properties, such as electrical resistivity, to reconstruct the actual conditions that yielded the measurements.

Julian day Day of the year measured from January 1, without regard to months.

linearized Converted from an irregular or curved path into a straight line to simplify computations.

paleochannel Depressions cut by rivers into underlying material during periods of lower sea level, and now submerged by rising sea level and often partially or fully buried by sediments.

peat Organic-rich sediment deposited beneath wetlands.

potential The property of electrical potential energy divided by electrical charge, usually measured in volts.

profile A cross-section produced from geophysical data.

pseudosection An image plotting apparent electrical resistivity data against position along a traverse line; this image is produced as an intermediate step to reconstructing the true electrical properties and geometry of a measured transect.

resistivity A measure of how strongly a material or mixture opposed the flow of electric current through it.

saline At or near the saltiness of seawater.

SEG-Y An open standard file format developed by the Society of Exploration Geophysicists for storing geophysical data.

seismic reflection A geophysical technique that used sound waves to detect variations in geologic properties below the Earth's surface.

shapefile A data format commonly used for geographic information system files.

starboard A nautical term for the right side of a ship when facing toward the front (bow).

streamer A cable towed behind a ship that contains electrodes or acoustic sensors.

surface water Water occurring in the form of a stream, river, lake, estuary, or ocean.

trackline An individual segment of a larger marine geophysical survey, often assigned a sequential number that corresponds to the order in which that interval of data was collected.

voltage The driving force that moves an electrical current between two points, measured in volts. 


\section{Figures}

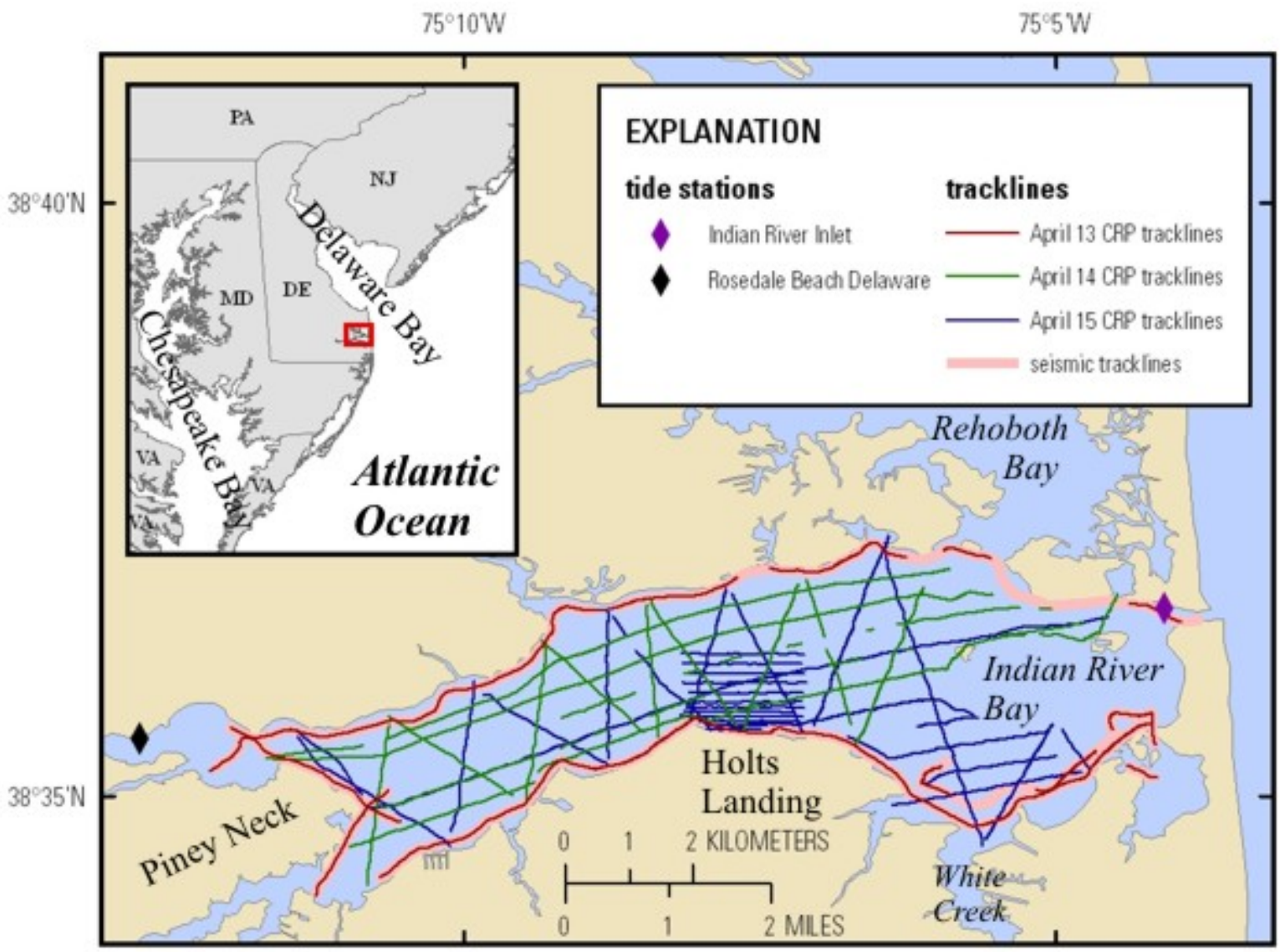

Figure 1. Location map showing the continuous resistivity profiling (CRP) tracklines of the survey in Indian River Bay, Delaware, in April 2010. A subset of these lines was also surveyed using a chirp seismic system (pink lines). 


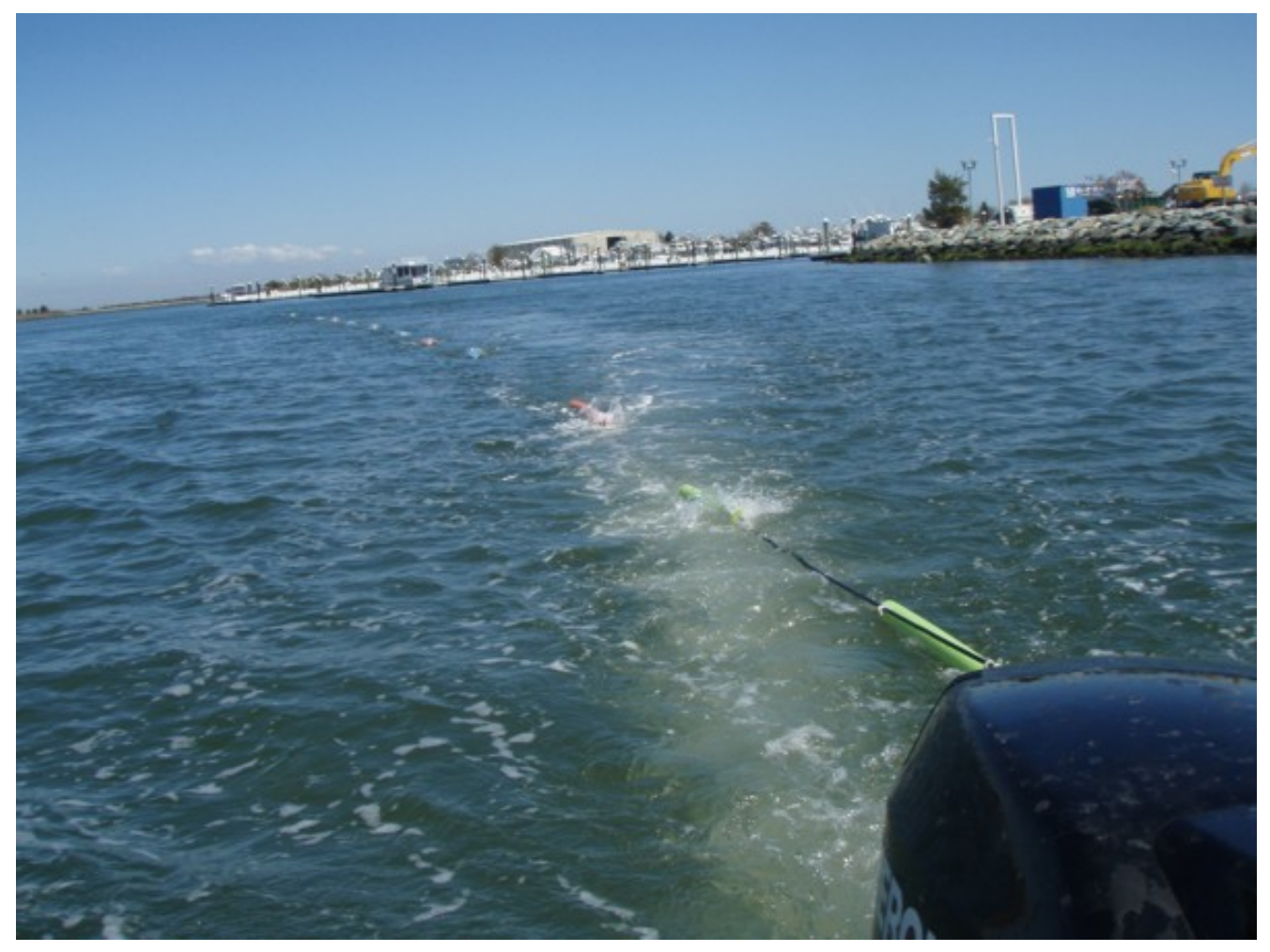

Figure 2. Photograph of the continuous resistivity profiling streamer deployed behind the survey boat. Foam flotation is attached to the cable between each electrode. Photograph by Adrian Green, U.S. Geological Survey. 


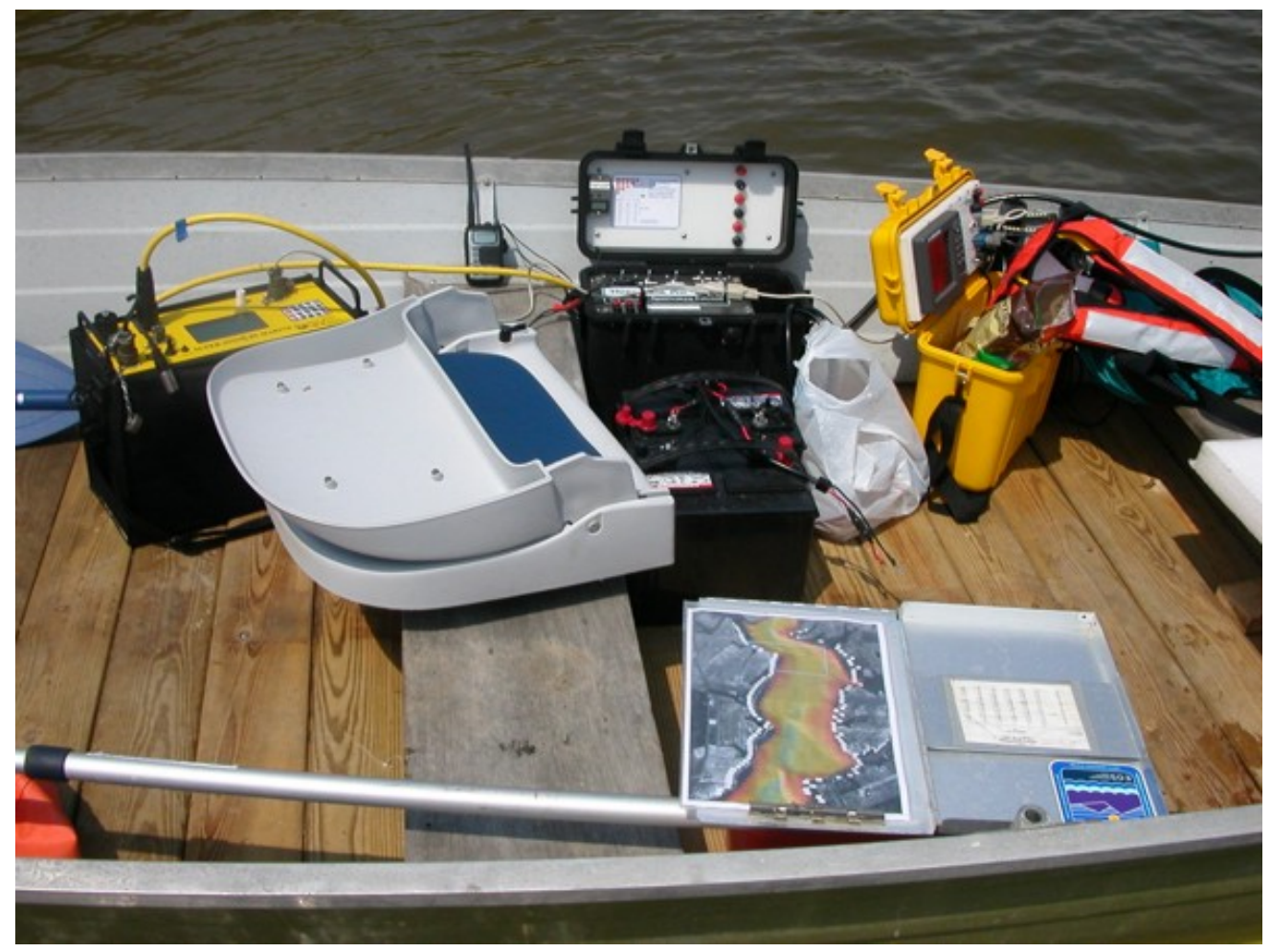

Figure 3. Photograph of the continuous resistivity profiling data acquisition system in a small survey boat (photograph is from a different survey). The yellow box on the left side of the photograph is the Advanced Geosciences, Inc. SuperSting R8 Marine resistivity meter, the black box in the middle manages the battery power to the system, and the yellow box on the right side contains the Lowrance Global Positioning System-enabled fathometer. Photograph by John Bratton, National Oceanic and Atmospheric Administration. 


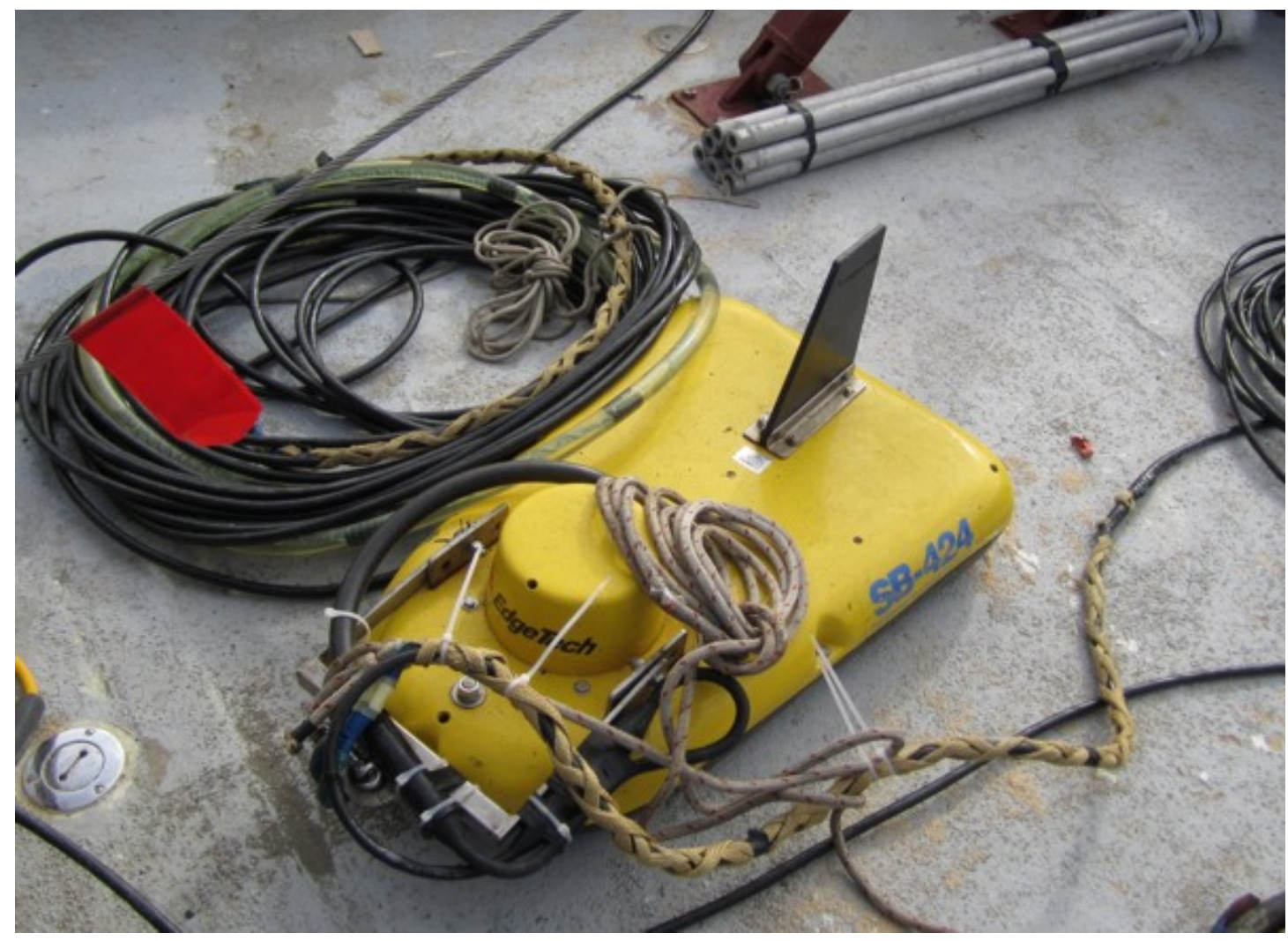

Figure 4. Photograph of the SB-424 chirp seismic transducer on the deck of a survey ship (photograph is from a different survey). Photograph by Charles Worley, U.S. Geological Survey. 

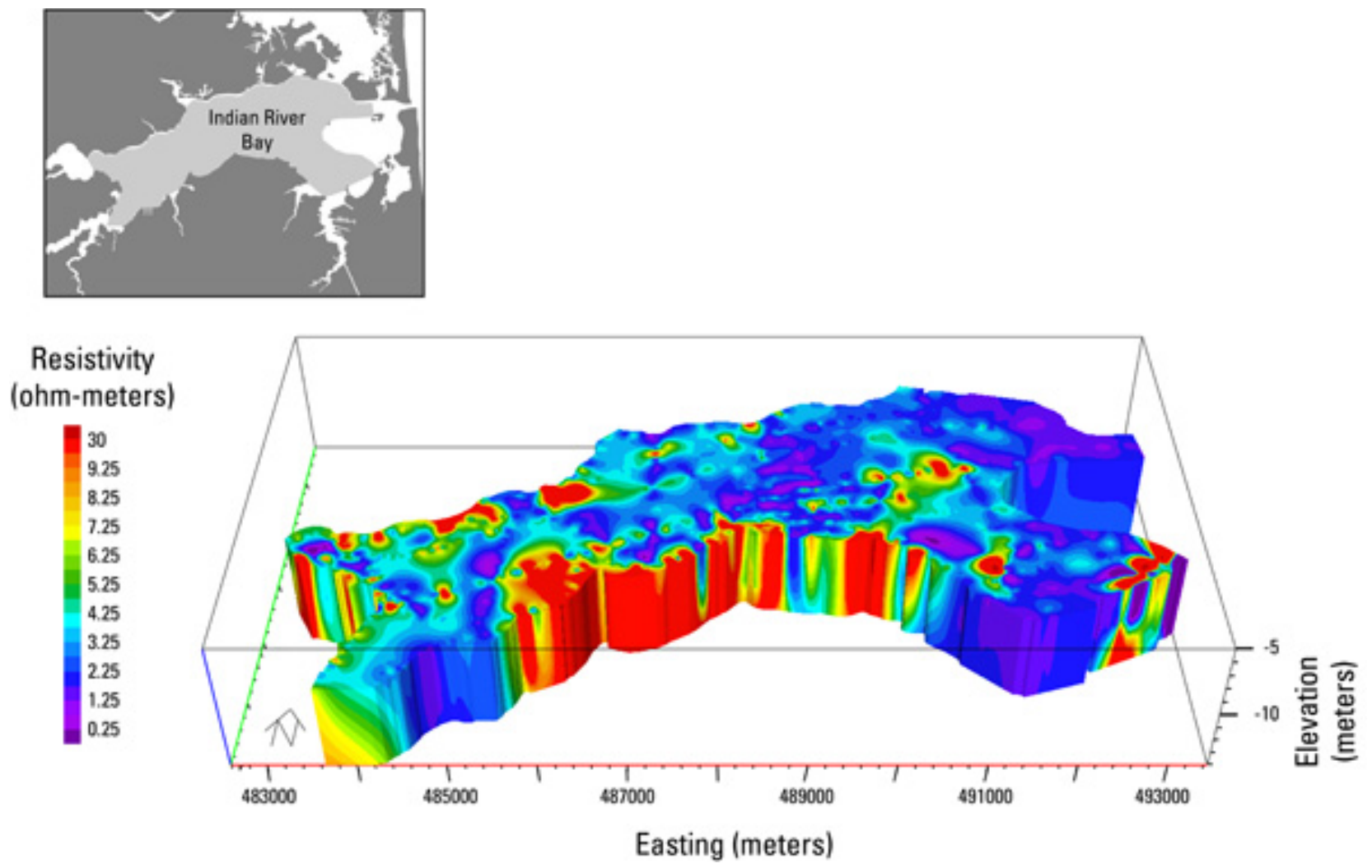

Figure 5. Oblique view of a horizontal slice through a three-dimensional model developed using continuous resistivity profiling data from the Indian River Bay collected in April 2010. The slice represents a constant depth of 8 meters below sea level. Warmer colors (yellow, orange, and red) represent regions with submarine groundwater of low salinity (high resistivity). The location map shows the bounds of the three-dimensional model in light gray. The Easting represent Universal Transverse Mercator Zone 18 coordinates. 


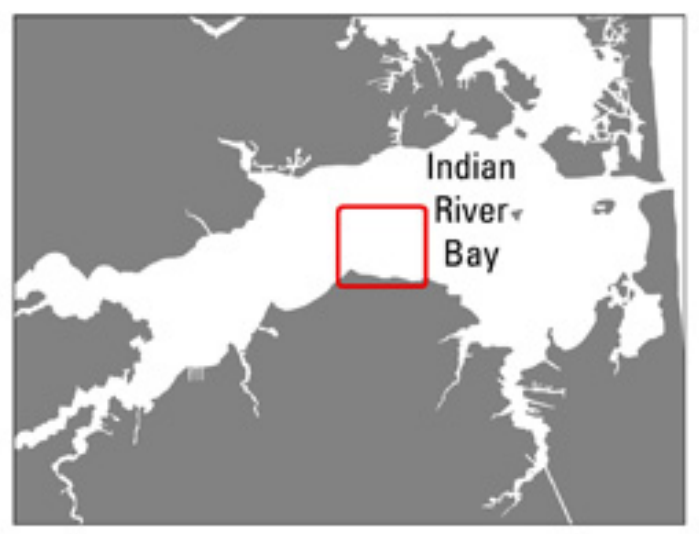

\section{Resistivity (ohm-meters)}
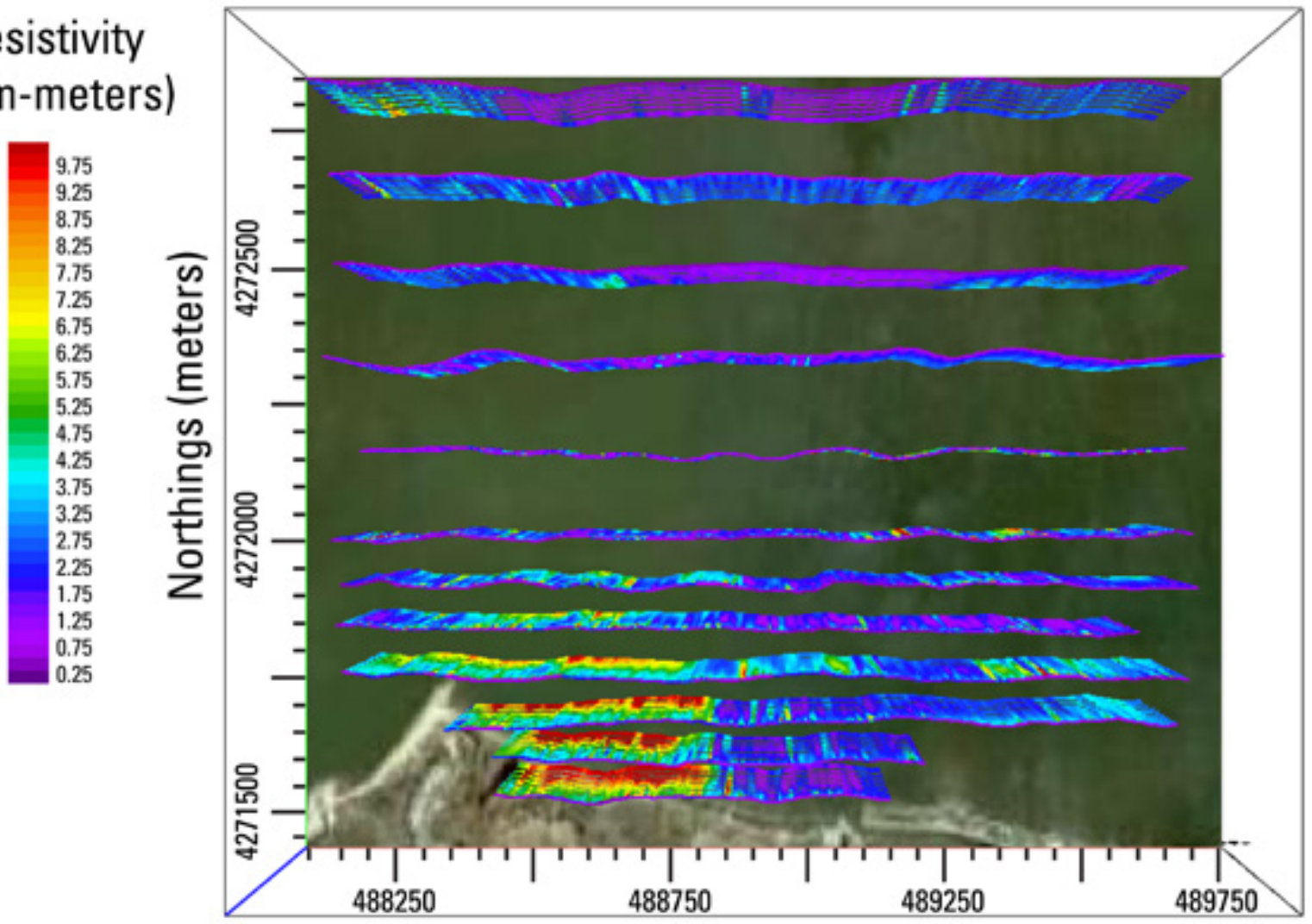

Eastings (meters)

Figure 6. Perspective view from above of continuous resistivity processed data from the shore-parallel surveys collected off Holts Landing. The location map shows the bounds of the perspective view in Indian River Bay. The background orthophoto image was acquired from the Delaware Geological Survey (accessed May 2010, http://datamil.delaware.gov/). 


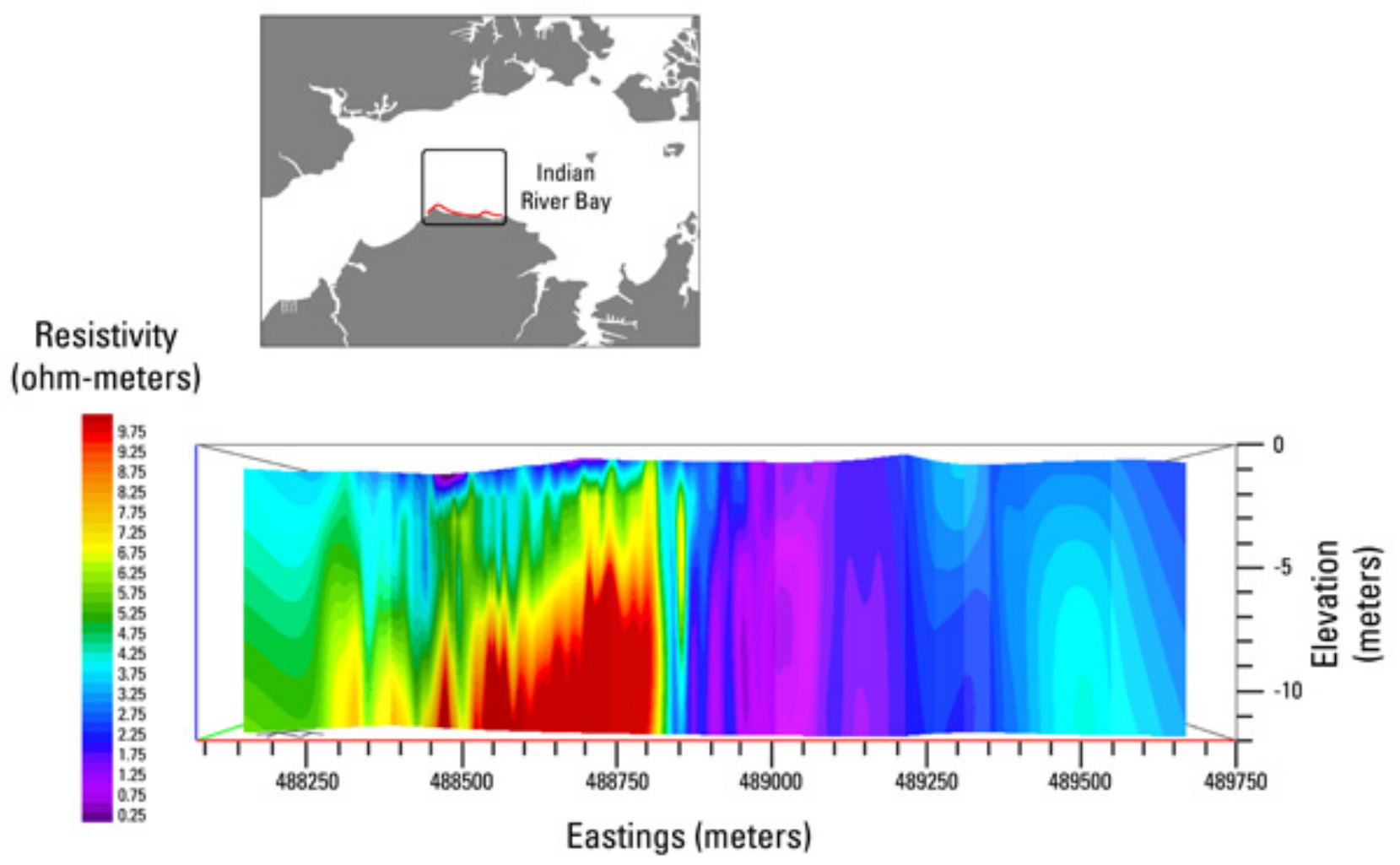

Figure 7. Cross-section view of a vertical slice through a three-dimensional model of the continuous resistivity profile data. The perspective is facing offshore (north). A high-resistivity (fresh groundwater represented by red colors) anomaly to the left (west) lies beneath a filled paleochannel shown in figure 8 . The red line in the location map marks the position of the slice. Vertical exaggeration is 40x. 

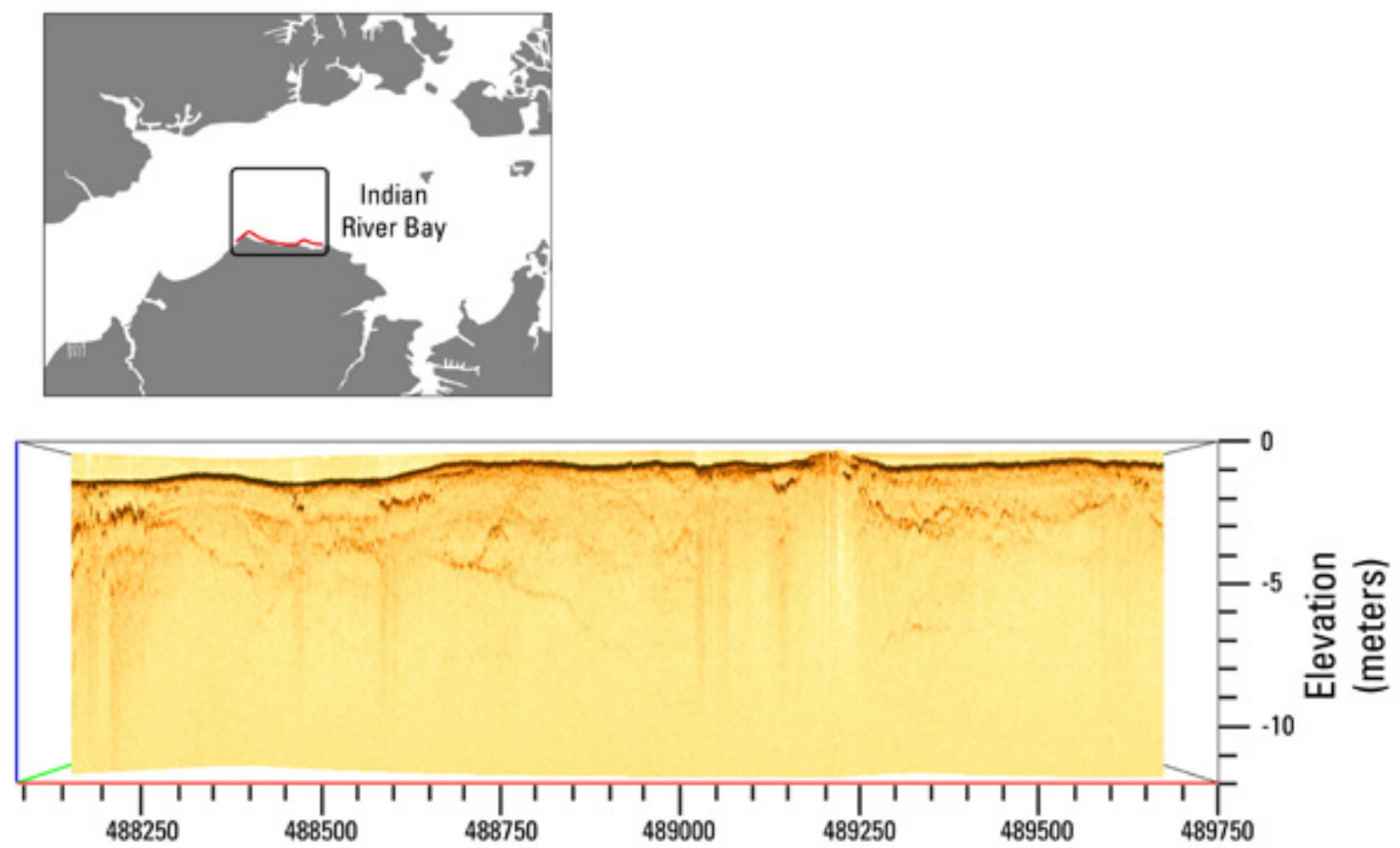

\section{Eastings (meters)}

Figure 8. Chirp seismic-reflection profile collected near the Holts Landing shoreline along the same traverse (as indicated by the red line in the location map) and with the same perspective as figure 7. The seismic profile shows a complex paleochannel 2 to 4 meters deep on the left side of the image (west), which corresponds with the position of the high-resistivity anomaly shown in figure 7 . Vertical exaggeration is 40x, 1500 meters per second was used to convert two-way travel time to depths. 

Prepared by the Pembroke Publishing Service Center

For more information concerning this report, contact:

\section{Director}

Woods Hole Coastal and Marine Science Center

U.S. Geological Survey

384 Woods Hole Road

Quissett Campus

Woods Hole, MA 02543-1598

WHSC_science_director@usgs.gov

508-548-8700 or 508-457-2200

or visit our Web site at:

http://woodshole.er.usgs.gov/ 
